str. 1

Jasieński M (2012) Czy kooperacja sprzyja innowacyjności? Przegląd Organizacji 12 (875): 24-27.

\title{
CZY KOOPERACJA SPRZYJA INNOWACYJNOŚCI?
}

Michat Jasieński

Czy istnieje związek pomiędzy procesami społecznymi, zaufaniem, pomocą wzajemną, a zdolnością, objawiającą się na poziomie zespołu lub społeczności, do generowania nowych pomysłów? Poniższy tekst jest próbą przeglądu niedawnej literatury na ten temat. Nie jest to bynajmniej tylko kwestia modeli teoretycznych, lecz empiryczna, która powinna być opisana przez analizę danych, charakteryzujących z jednej strony - kapitał społeczny, czyli gotowość do kooperacji, a z drugiej strony - innowacyjność. Obie te cechy społeczności albo zespołu nie są łatwe do zmierzenia [Jasieński, 2011; Jasieński, Rzeźnik, 2012]. Poza tym, należy ustalić na jakim poziomie ogólności przeprowadzamy analizy, to znaczy czy opierają się one na danych o krajach, regionach, firmach czy zespołach pracowniczych.

\section{UCZESTNICY KOOPERACJI}

Traktując firmy jako „organizmy”, które tworzą partnerstwa, sieci albo pakty, można wykazać, że utrzymywanie aktywnych relacji w środowisku firmy sprzyja jej rozwojowi i sukcesowi biznesowemu [Street, Cameron, 2007]. Oczywiście, diabeł tkwi w szczegółach: na każdym etapie rozwoju firmy (od opracowania innowacji, poprzez jej komercjalizację, do fazy wzrostu firmy), różne aspekty tychże sieci kontaktów mają mniejsze lub większe znaczenie [co badano np. na przykładzie SME w sektorze naukowo-technologicznym, Partanen i in., 2008]. Czy coś odróżnia firmy, które używają kooperacji jako głównego sposobu na bycie innowacyjnym [tzw. cooperationbased innovators, Barge-Gil, 2010]? Analiza wyników 2004 Spanish Innovation Survey pokazała, że były to najczęściej firmy małe oraz działające poza sektorem wysokich technologii.

Kalifornijska Dolina Krzemowa oraz tzw. Route 128 pod Bostonem są często przywoływane jako przykłady dwóch, skrajnie odmiennych, sposobów zorganizowania przestrzeni biznesowych, w których zjawiska sieciowe i kooperacja znajdowały bardzo różne poziomy ekspresji. W latach 1980-tych, w Kalifornii - sieci firm IT (wspomagane przez aktywność lokalnych stowarzyszeń użytkowników i hobbystów) rozkwitały, napędzając dynamiczny rozwój wynalazczości. Dla kontrastu, w rejonie Bostonu - dominował klimat nieufności i izolacji firm, co doprowadziło w szeregu przypadków do schyłku lub upadku nawet dużych korporacji (np. Digital Equipment Corporation). Kooperencja (ang. coopetition), czyli typ relacji kooperacyjnych pomiędzy konkurentami, znalazł przykłady właśnie w Dolinie Krzemowej, ale jest to zagadnienie zasługujące na osobne omówienie. Ponadto, skłonność do tworzenia sieci nie rozwija się jednakowo łatwo w różnych sektorach - na przykład, w przemyśle farmaceutycznym dominowały, dłużej niż w innych sektorach wysokich technologii, formy kooperacji oparte na spółkach joint venture albo na tradycyjnych umowach o współpracy naukowobadawczej lub o wymianie licencji.

Najbardziej oczywistym rodzajem zależności pomiędzy kooperacją i innowacją jest kooperacja pomiędzy przemysłem i światem akademickim, który pełni rolę generatora wynalazków. Zmiana wyników badań podstawowych w komercyjne produkty lub usługi nie jest nigdy łatwa - jest to wąskie gardło dla rozwoju innowacyjnej przedsiębiorczości. Jak stwierdzono, główna słabość w potencjale konkurencyjnym firm amerykańskich i europejskich wynikała właśnie $\mathrm{z}$ ich nieumiejętności na tym etapie, a nie $\mathrm{z}$ osłabionego potencjału $\mathrm{B}+\mathrm{R}$ (oczywiście, mam na myśli analizy porównujące konkurencyjność firm w obrębie USA i 
str. 2

Europy, czyli obszary reprezentujące wysoki poziom kultury biznesowej). Promowanie kooperatywnego udziału firm spoza USA lub spoza Europy w programach badawczych finansowanych z, odpowiednio, amerykańskich lub europejskich środków publicznych, może mieć bardzo pozytywny wpływ zarówno na rozwój przedsiębiorczości w innych regionach świata, a jednocześnie może stymulować działania $B+R$ w USA i Europie.

Większe zyski są generowane przez kooperację i maksymalizację różnorodności pomysłów, niż przez izolację i wykluczanie potencjalnych partnerów, tylko na podstawie kryteriów geograficznych lub politycznych. Analogicznie, w krajowych kręgach akademickich i badawczo-rozwojowych, owe generowanie i wdrażanie wynalazków postępowałoby znacznie bardziej dynamicznie, gdyby nie hierarchiczna i nie-merytokratyczna kultura organizacyjna uczelni i jednostek $\mathrm{B}+\mathrm{R}$, prowadząca właśnie do wykluczania i niewykorzystywania potencjału intelektualnego młodszych, a więc często najbardziej optymistycznych, dynamicznych i twórczych, pracowników nauki [Jasieński, 2011, 2012].

MŚP są uczestnikami bogatej palety interakcji opartych na kooperacji: pionowych (pomiędzy firmami a klientami oraz dostawcami) oraz poziomych (pomiędzy równorzędnymi firmami, albo firmami i uczelniami, instytuacjami badawczymi lub agencjami rządowymi). Analiza rezultatów takich interakcji na próbie 137 firm produkcyjnych w Chinach pokazała, że innowacyjność firmy pozostaje pod korzystnym wpływem kooperacji z innymi firmami albo jednostkami badawczymi, natomiast kooperacja $z$ agencjami rządowymi nie ma na innowacyjność żadnego wpływu [Zeng i in., 2009]. Ostatnie stwierdzenie podaję ku przestrodze krajowych animatorów przedsiębiorczości, aczkolwiek należy docenić bardzo pozytywne działania MNiSW oraz NCBiR, na przykład mające formę programu „Kreator innowacyjności - wsparcie innowacyjnej przedsiębiorczości akademickiej” oraz aktywność Polskiej Agencji Rozwoju Przedsiębiorczości i lokalnych organizacji (jak, na przykład, Centrum Innowacji Wojewódzkiego Klubu Techniki i Racjonalizacji w Katowicach, organizatora Targów Innowacji Gospodarczych i Naukowych INTARG).

Może istnieć również współpraca pomiędzy firmami a klientami przy tworzeniu innowacji - feedback od klientów pozwala uwzględniać ich preferencje. Także w tym obszarze znajduje się kwestia społecznej akceptacji wprowadzania niektórych rodzajów innowacji, na przykład tych związanych z nowymi żródłami energii. Wpływ tego rodzaju kooperacji - z użytkownikami, na zdolność generowania przez firmy innowacji produktowych i procesowych był badany na próbie prawie 12 tysięcy firm produkcyjnych w Hiszpanii [Sanchez-Gonzalez i in., 2008].

Również rodzaj tworzonych form kooperacji zależy od branży. Wśród firm branży elektronicznej z rejonu Wiednia, pionowe relacje (z klientami lub dostawcami) były częstsze niż poziome (z innymi producentami lub ośrodkami badawczymi) [Fischer, Varga, 2002]. W budownictwie, kooperacja może pojawiać się w relacjach pomiędzy wykonawcami i pod-wykonawcami, dostawcami materiałów budowlanych, agencjami rządowymi, pracowniami architektonicznymi, inżynierami i, oczywiście, klientami [Miozzo, Dewick, 2004]. Siła tych relacji jest, według autorów, opowiedzialna za dobrą kondycję branży budowlanej w niektórych krajach europejskich.

Częstość występowania innowacji produktowych, procesowych i organizacyjnych zależy od sektora gospodarki i rozmiaru firmy, jak wykazali Tether i Tajar [2008] w badaniach 2500 europejskich firm; innowacje produktowe, na przykład, są najczęstsze w firmach nowoczesnych technologii. Natomiast innowacja organizacyjna oparta na 
str. 3

kooperacji nie opiera się na wdrażaniu nowych rezultatów $B+R$, lecz na nowatorskich zmianach relacji, na przykład w usługach lub pomiędzy uczestnikami łańcucha dostaw [Tether, Tajar, 2008].

\section{POŻYTKI Z KOOPERACJI}

Jakie są zyski z „usieciowienia”, czyli mówiąc fachowym żargonem, „,networkingu”? Jednym z mechanizmów, dzięki którym w sieci powstają więzi kooperacji, jest odwzajemnianie, czyli wzajemna wymiana aktów pomocy. Teoria altruizmu odwzajemnionego, początkowo rozwinięta przez biologa Roberta Triversa w zastosowaniu do darwinowskiej teorii ewolucji, została rozwinięta przez politologa Roberta Axelroda i znalazła zastosowanie w świecie nauk społecznych [Jasieński, 2011]. Kooperacja jest kluczem do zyskania efektu synergii pomiędzy umiejętnościami i zasobami partnerów.

Kooperacja pomiędzy firmami jest w pierwszym rzędzie korzystaniem z dostępu do cudzej wiedzy. Podstawową funkcją sieci społecznych jest także wymiana nieformalnych informacji pomiędzy firmami, klientami, dostawcami, oraz instytucjami otoczenia biznesu (takimi jak np. stowarzyszenia branżowe). Sieć społeczna, działająca w przypadku społeczności małych firm, pozwala np. na dzielenie się ryzykiem (wdrażania nowatorskich technologii) lub rozszerzenie frontu poszukiwań informacji i pozyskiwania klientów [Pittaway i in., 2004].

Kooperację można uznać też za strategię zabezpieczającą uczestników przed niepewnością: sieci kooperujących firm powinny być bardziej odporne, niż pojedyncza firma, na zmienność koniunktury, w czasie i przestrzeni. Kłopot w tym, że trudno takie, w końcu sensowne spekulacje, udowodnić poprzez analizę danych empirycznych [Rycroft, 2007]. Kwestia znacznie bardziej, wydawałoby się, oczywista, również nie jest wcale jasna. Mianowicie, okazuje się, że zależność pomiędzy innowacyjnością a sukcesem biznesowym firmy (z kategorii SME) nie jest uniwersalnie pozytywna i zależy od wielu czynników, takich jak wiek firmy, typ wprowadzonej innowacji i tzw. kontekst kulturowy. Czasami więc innowacyjność popłaca, a czasami nie. Tym trudniejsze są badania wpływu innowacyjności na życie całego regionu - opierać się muszą na naprawdę mocnych danych, aby były realistyczne.

Analiza zysków z kooperacji wśród firm działających w Zhongguancun Science Park w Pekinie, najbardziej innowacyjnym obszarze w Chinach, pokazała, że kooperacja z firmami zagranicznymi jest rzeczywiście źródłem innowacyjnych pomysłów dla lokalnych firm [Liefner i in., 2006]. Wśród start-upów biotechnologicznych już dawno udokumentowano istnienie istotnego związku kooperatywności firm z ich potencjałem innowacyjnym. Zaufanie budowane pomiędzy firmami uczestniczącymi np. w łańcuchu dostaw okazało się być ważnym predyktorem sukcesu w biznesie [Panayides, Lun, 2009].

Z badań ponad 1300 małych firm w Szkocji i Północej Anglii wynika, że istnieje dodatnia korelacja pomiędzy sukcesem innowacyjnego produktu a poziomem współpracy z klientami oraz z sektorem publicznym. Z kolei kooperacja z dostawcami i sektorem akademickim związana jest z sukcesem innowacji procesowych [Freel, Harrison, 2006]. Innowacyjność spin-offów, wśród badanych 1500 firm ze wschodnich Niemiec, rosła z intensywnością kooperacji jaką firmy utrzymywały z lokalnymi jednostkami badawczymi i uczelniami [Lejpras, Stephan, 2011]. Jednak kooperacja, zwłaszcza z cudzoziemcami, nie jest łatwa i bezproblemowa i czasami kończy się porażką - francuski Community Innovation Survey wykazał, że 14\% firm współpracujących z zakresie B+R porzuciło innowacje z powodu rozpadu kooperacji [Lhuillery, Pfister, 2009]. 
Kooperacja wpływa nie tylko na zewnętrzny wizerunek firmy, ale kooperatywne więzi utrzymywane przez organizację na poziomie całego ekosystemu, w którym organizacja działa, zmieniają relacje wewnątrz organizacji. Innowacje i związane $\mathrm{z}$ ich wprowadzeniem innowacyjne zmiany procesów produkcji stwarzają potrzebę kooperacji wewnątrz organizacji, ponieważ zmiany takie często budzą naturalny opór wśród pracowników [Harrisson i in., 2001]. Kierownictwo, związki zawodowe oraz pracownicy tworzą koalicje i porozumienia, których forma może być opisywana przez takie same reguły (sformalizowane przez teorię gier) jak kooperacja i konflikt pomiędzy organizacjami.

Wykazano, że innowacyjność firmy koreluje dodatnio ze stosowaniem rotacji na stanowiskach pracy (internal functional flexibility), a negatywnie $\mathrm{z}$ tym jak łatwo firma skłonna jest zwalniać pracowników (external numerical flexibility, EMF) i stosować outsourcing. Jednocześnie, uczestniczenie przez firmę w sieci opartej na kooperacji pomiędzy firmami, pozwala zredukować negatywny wpływ wysokiej EMF na innowacyjność firmy. Dostęp do wiedzy na temat nowych produktów i nowych procesów oraz dyfuzja tej wiedzy wewnątrz firmy postępują łatwiej w firmach aktywnie kooperujących z innymi firmami [Martinez-Sanchez i in. 2009].

\section{WARUNKI KOOPEROWANIA}

Stopień podobieństwa pomiędzy firmami kooperującymi ze sobą również może wpływać na poziom pożytku (rozumianego jako zdolność do generowania innowacji) jaki płynie dla nich z tej interakcji [Garcia, Velasco, 2010]. A więc, każda firma powinna budować swoją sieć współpracy B+R zwracając uwagę na to jak bardzo jest „technologicznie spokrewniona” z innymi firmami, jak to nazywają autorzy badania, ponieważ wpłynie to na jej innowacyjny potencjał.

Decyzja o podjęciu współpracy powinna z pewnością być oparta na starannej ocenie potencjalnego partnera [de Faria i in., 2010]. Ponadto, skłoność wejścia we współpracę (formalną lub nieformalną) jest większa wtedy gdy firma ma opracowane procedury chroniące jej własność intelektualną przed ewentualnymi „knowledge spillovers". Wśród niemieckich firm, kooperacja nieformalna jest częstsza i ważniejsza niż formalna, aczkolwiek ta ostatnia dominuje $\mathrm{w}$ firmach większych, które są zaangażowane $\mathrm{w}$ duże i kosztowne projekty B+R [Bonte, Keilbach, 2005]. Ogólnie, wśród niemieckich firm produkcyjnych istnieje dodatnia korelacja pomiędzy intensywnością $B+R$ wewnątrz firmy i skłonnością firmy do tworzenia wspólnych działań $B+R$ z innymi firmami [Becker, Dietz, 2004]. Izolacja firmy, w błędnym poczuciu, że utajnianie zwiększy jej przewagę konkurencyjną, nie jest tak efektywna jak wzmacnianie sieci współpracy naukowo-badawczej.

Pozioma lub pionowa kooperacja firmy wpływa na wiele aspektów modelu biznesowego, na przykład, na stosunek wobec zabezpieczania własności intelektualnej. Małe firmy, które nie są aktywnymi partnerami w kooperacji związanej z B+R, nastawiają się na utrzymywanie tajemnicy handlowej albo szybkość wdrożeń (i związaną z tym przewagę na rynku), a nie ochronę poprzez patenty. Na drugim biegunie są firmy intensywnie kooperujące ze światem $B+R$ - tutaj patentowanie wynalazków to dominująca metoda ochrony własności intelektualnej.

Kooperacja może być również rozumiana jako sytuacja, w której dozwolony jest pewien poziom wzajemnej imitacji pomysłów przez producentów - okazuje się, że innowacyjność może rozwijać się (zgodnie z analizami tzw. cooperative innovation model), a bardziej restrykcyjne podejście do ochrony własności intelektualnej może 
str. 5

mieć na innowacyjność wpływ negatywny. Na przykład, w branży ubraniowej innowacja jest koniecznością wymuszaną przez nieustanne zmiany mody, a ponadto autorzy nowych strojów nie mogą skutecznie chronić swoich pomysłów przed skopiowaniem, ponieważ całość pomysłu (w postaci stroju wiszącego na wieszaku) jest dostępna dla każdego klienta i konkurenta.

Cechy kultury narodowej mogą zwiększać lub zmniejszać skłonność firm do kooperowania z innymi firmami, a z drugiej strony ułatwiać lub utrudniać elastyczność pracy wewnątrz firmy [Love, Roper, 2004]. Na przykład, normy społeczne w Niemczech popierają współpracę pomiędzy firmami przy wdrażaniu innowacji, ale jednocześnie formalny system relacji pomiędzy pracownikami w firmie oraz sztywny system szkoleń pracowniczych utrudniają osiągnięcie elastyczności niezbędnej dla dobrego poziomu innowacyjności. W firmach brytyjskich łatwiej wprowadzić elastyczne sposoby definiowania obowiązków pracowniczych oraz rotację na stanowiskach pracy (multifunctional working), ale trudność pojawia się na poziomie relacji pomiędzy firmami. Tutaj oczekiwana jest większa konkurencyjność i trudniej wypracować kooperację między firmami opartą na zaufaniu [Love, Roper, 2004].

Z kooperacją pomiędzy firmami związane są również kwestie filozoficzne, wykraczające poza biznes i zarządzanie. Na przykład, rozrastanie się sieci kooperatywnych interakcji pomiędzy firmami, w świecie, w którym samotny przedsiębiorca to anachronizm, zmusza nas do zrewidowania tak ważnych pojęć jak kartel i zmowa cenowa. Przepisy regulujące konkurencję muszą uwzględniać podobieństwo kooperacji dozwolonej i sprzyjającej innowacyjności od kooperacji zakazanej, naruszającej interesy klientów i ducha konkurencji.

dr Michat Jasieński, prof. WSB-NLU

Centrum Innowatyki, Wyższa Szkoła Biznesu - National-Louis University

ul. Zielona 27, 33-300 Nowy Sącz

tel.18-44-99-470, jasienski@post.harvard.edu

\section{STRESZCZENIE}

\section{Czy kooperacja sprzyja innowacyjności?}

Celem przeglądu jest odpowiedź na pytanie czy istnieje związek pomiędzy kooperacją, zaufaniem lub pomocą wzajemną (kultywowaną pomiędzy firmami lub instytucjami, a nie pracownikami wewnątrz firmy), a poziomem innowacyjności firm będących uczestnikami kooperacji. Wykazano, że innowacyjność firm często wzrasta pod wpływem kooperacji z innymi firmami albo jednostkami badawczymi, ale raczej nie z agencjami rządowymi. Duże znaczenie dla innowacyjności ma także kooperacja pionowa firmy (np. z dostawcami i klientami).

\section{SUMMARY}

\section{Does cooperation improve innovativeness?}

The paper explores the issue of a possible connection between cooperation, trust and mutual help (maintained by companies or institutions, and not among employees within the company) and the level of innovativeness of the companies which are active participants of cooperation. It can be shown that innovation potential of firms rises under the influence of cooperation with other firms of R\&D institutions, but cooperation with governmental agencies is not effective. Vertical cooperation (e.g. with suppliers and customers) is also important for the firm's innovativeness. 
str. 6

\section{BIBLIOGRAFIA}

BARGE-GIL A. Cooperation-based innovators and peripheral cooperators: An empirical analysis of their characteristics and behavior, "Technovation" 2010, 30, 195-206.

BECKER W., DIETZ J. R\&D cooperation and innovation activities of firms - evidence for the German manufacturing industry, "Research Policy" 2004, 33, 209-223.

BONTE W., KEILBACH M. Concubmage or marriage? Informal and formal cooperations for innovation, "International Journal of Industrial Organization" 2005, 23, 279-302.

DE FARIA P., LIMA F., SANTOS R. Cooperation in innovation activities: The importance of partners, "Research Policy" 2010, 39, 1082-1092.

FISCHER M. M., VARGA A. Technological innovation and interfirm cooperation: An exploratory analysis using survey data from manufacturing firms in the metropolitan region of Vienna, "International Journal of Technology Management" 2002, 24, 724-742.

FREEL M. S., HARRISON R. T. Innovation and cooperation in the small firm sector: Evidence from 'Northern Britain', "Regional Studies" 2006, 40, 289-305.

GARCIA C. Q., VELASCO C. A. B. Technological relatedness in interfirm cooperation agreements and the generation of innovations, "Cuadernos De Economia Y Direccion De La Empresa" 2010, 43-67.

HARRISSON D., LAPLANTE N., ST-CYR L. Cooperation and resistance in work innovation networks, "Human Relations" 2001, 54, 215-255.

JASIEŃSKI M. Googleinteligencja i rozkwit kapitału społecznego, „Znak” 2011, 668 (styczeń), 36-42.

JASIEŃSKI M. Edukacja menedżerów w Polsce: więcej heurystyki i jakości. W: „Edukacja ekonomiczna wobec przemian otoczenia społeczno-gospodarczego" (J. Dietl, Z. Sapijaszka, red.) 2012, str. 63-68. Fundacja Edukacyjna Przedsiębiorczości, Łódź.

JASIEŃSKI M., RZEŹNIK M. Innovatics - a new toolbox of skills for innovative production managers. W: „Innovations in management and production engineering” (R. Knosala, red.) 2012, str. 63-71. Oficyna Wydawnicza Polskiego Towarzystwa Zarządzania Produkcją, Opole.

LEJPRAS A., STEPHAN A. Locational conditions, cooperation, and innovativeness: Evidence from research and company spin-offs, "Annals of Regional Science" 2011, 46, 543-575.

LHUILLERY S., PFISTER E. R\&D cooperation and failures in innovation projects: Empirical evidence from french CIS data, "Research Policy" 2009, 38, 45-57.

LIEFNER I., HENNEMANN S., XIN L. Cooperation in the innovation process in developing countries: Empirical evidence from Zhongguancun, Beijing, "Environment and Planning A" 2006, 38, 111-130.

LOVE J. H., ROPER S. The organisation of innovation: Collaboration, cooperation and multifunctional groups in UK and German manufacturing, "Cambridge Journal of Economics" 2004, 28, 379-395.

MARTINEZ-SANCHEZ A., VELA-JIMENEZ M. J., PEREZ-PEREZ M., DE-LUIS-CARNICER P. Inter-organizational cooperation and environmental change: Moderating effects between flexibility and innovation performance, "British Journal of Management" 2009, 20, 537-561.

MIOZZO M., DEWICK P. Networks and innovation in European construction: Benefits from inter-organisational cooperation in a fragmented industry, "International Journal of Technology Management" 2004, 27, 68-92.

PANAYIDES P. M., LUN Y. H. V. The impact of trust on innovativeness and supply chain performance, „International Journal of Production Economics” 2009, 122, 135-46.

PARTANEN J., MOLLER K., WESTERLUND M., RAJALA R., RAJALA A. Social capital in the growth of science-and-technology-based SMEs, ,Industrial Marketing Management” 2008, 37, 513-522. 
str. 7

PITTAWAY L., ROBERTSON M., MUNIR K., DENYER D., NEELY A. Networking and innovation: $a$ systematic review of the evidence, "International Journal of Management Reviews" 2004, 5-6, 137-168.

RYCROFT R. W. Does cooperation absorb complexity? Innovation networks and the speed and spread of complex technological innovation, "Technological Forecasting and Social Change" 2007, 74, 565-578.

SANCHEZ-GONZALEZ G., GONZALEZ-ALVAREZ N., ANTOLIN M. N. The effects of cooperating with users concerning the type of innovation developed, "Innovar - Revista de Ciencias Administrativas y Sociales" 2008, 18, 87-110.

STREET C. T., CAMERON A.-F. External relationships and the small business: A review of small business alliance and network research,"Journal of Small Business Management" 2007, 45, 2, 239-266.

TETHER B. S., TAJAR A. The organisational-cooperation mode of innovation and its prominence amongst European service firms, "Research Policy" 2008, 37, 720-739.

ZENG S. X., XIE X. M., TAM C. M. Relationship between cooperation networks and innovation performance of SMEs, "Technovation" 2009, 30, 181-194. 